\title{
Antimicrobial Activity of Melinjo Seed and Peel Extract (Gnetum gnemon) Against Selected Pathogenic Bacteria
}

\author{
ADOLF JAN NEXSON PARHUSIP ${ }^{1 *}$ AND AZIS BOING SITANGGANG ${ }^{2,3}$ \\ ${ }^{I}$ Department of Food Technology, Universitas Pelita Harapan, MH. Thamrin Boulevard, 1100 Lippo Village, \\ Tangerang, Indonesia; \\ ${ }^{2}$ Department of Food Science and Technology, Institut Pertanian Bogor, Darmaga, Bogor 16680, Indonesia; \\ ${ }^{3}$ Southeast Asian Food and Agricultural Science and Technology (SEAFAST) Center, Institut Pertanian Bogor, \\ Darmaga, Bogor 16680, Indonesia
}

\begin{abstract}
Melinjo (Gnetum gnemon) is an Indonesian native plant which has not been widely accepted due to its limited utilization. Mainly, melinjo is consumed as an ingredient to make a vegetable dish or as raw material of 'emping'. The purpose of this research was to study the antimicrobial activity of the melinjo seed extract and melinjo peel extract. In this study, extraction from melinjo seed and peel was conducted by maceration using three kinds of solvent: ethanol, ethyl acetate and hexane for 24 $\mathrm{h}$ at room temperature. The results showed that none of the melinjo extracts (concentration from $5 \%-25 \% \mathrm{w} / \mathrm{v}$ ) could inhibit the growth of Aspergillus flavus IPBCC 88.030; whereas for Bacillus cereus ATCC 10876, Staphylococcus aureus ATCC 25953, and Enterobacter aerogenes ATCC 13048 there was efficient inhibition by 5\% (w/v) of melinjo seed-ethanol extract. The minimal inhibitory concentration (MIC) value of melinjo extract was ranged from $0.26 \mu \mathrm{g} \mathrm{mL}^{-1}$ to $1.46 \mu \mathrm{g} \mathrm{mL}^{-1}$, whilst the minimal bactericidal concentration (MBC) value was ranged from $1.02 \mu \mathrm{g} \mathrm{mL}{ }^{-1}$ to $6.04 \mu \mathrm{g} \mathrm{mL}^{-1}$. The inhibitory capacity of extract had a similar level as compared to 10 ppm penicillin G on B. cereus ATCC 10876 as well as on S. aureus ATCC 25953. Furthermore, as compared to $10 \mathrm{ppm}$ streptomycin, the inhibitory capacity of the extract was equal for the all tested bacteria. Cell wall deformation was observed using SEM, and confirmed by the presence of ions $\left(\mathrm{Ca}^{2+}\right.$ and $\left.\mathrm{K}^{+}\right)$outside of the cells, detected by means of AAS.
\end{abstract}

Key words: Melinjo, Gnetum gnemon, extraction, antimicrobial, inhibition

Melinjo (Gnetum gnemon) adalah tanaman lokal Indonesia yang belum dimanfaatkan secara luas. Umumnya melinjo dikonsumsi sebagai komponen dalam pembuatan sayur ataupun dalam pembuatan kue kering yang dikenal dengan emping. Tujuan penelitian ini adalah mengkaji aktivitas antibakteri ekstrak melinjo yang berasal dari biji dan kulit melinjo. Proses ekstraksi dilakukan dengan metode maserasi menggunakan tiga jenis pelarut, yaitu etanol, etil asetat, dan heksana selama 24 jam pada suhu ruang. Hasil ekstraksi biji melinjo (5\% w/v) dengan menggunakan pelarut etanol sampai dengan konsentrasi $25 \%(\mathrm{w} / \mathrm{v})$, ternyata tidak menunjukkan aktivitas antifungal khususnya terhadap pertumbuhan Aspergillus flavus IPBCC 88.030; namun demikian ekstrak melinjo tersebut memiliki aktivitas antibakteri, khususnya terhadap Bacillus cereus ATCC 10876, Staphylococcus aureus ATCC 25953, dan Enterobacter aerogenes ATCC 13048. Nilai minimal inhibitory concentration (MIC) dan minimal bactericidal concentration (MBC) dari ekstrak melinjo untuk berbagai bakteri yang diujikan berturut-turut berada pada selang $0.26 \mu \mathrm{g} \mathrm{mL}^{-1}$ hingga $1.46 \mu \mathrm{g} \mathrm{mL}^{-1}$, dan $1.02 \mu \mathrm{g} \mathrm{mL}^{-1}$ hingga $6.04 \mu \mathrm{gL}^{-1}$. Penghambatan ekstrak melinjo menunjukkan kemampuan yang hampir sama dengan $10 \mathrm{ppm}$ penisilin $\mathrm{G}$ terhadap bakteri contoh B. cereus ATCC 10876 dan S. aureus ATCC 25953, sedangkan jika dibandingkan dengan streptomisin, kemampuan penghambatan ekstrak melinjo hampir mirip dalam beberapa variasi konsentrasi. Uji konfirmasi berupa pengamatan struktur sel bakteri menggunakan SEM menunjukkan terjadinya perubahan pada struktur dinding sel bakteri dan hal ini diperkuat dengan adanya pengeluaran sejumlah ion yang menyusun dinding $\operatorname{sel}\left(\mathrm{Ca}^{2+}\right.$ and $\left.\mathrm{K}^{+}\right)$yang dikuantifikasi menggunakan AAS.

Kata kunci: Melinjo, Gnetum gnemon, ekstraksi, antimikrob, penghambatan

Melinjo (Gnetum gnemon) is native to IndoMalaya, belonging to the Gnetacea family (Kato et al. 2009; Kato et al. 2011). The size of the melinjo tree is about $50 \mathrm{ft}$ in height and it is often found in dry and humid forests of the region. Particularly in Indonesia, the distribution areas of this plant cover in Andaman, Sumatra and Java Island (Manner and Elevitch 2006). For Sumatra itself, the productivity of melinjo is more than 20,000 granules per year (Manner and Elevitch, 2006). It is a spontaneous re-growth species in fallow forests and commonly planted as a cultivated species in both backyard gardens and orchards or as hedges. In

*Corresponding author, Phone: (+62)-21-5460901, ext 1249, Fax: (+62)-21-5460910, E-mail: adolf.parhusip@uph.edu addition to those, melinjo has been utilized as a conservation farming component at the upland watershed in semi-arid climate (Hafif et al. 1995).

For local food products, melinjo seeds are commonly used as raw material for making 'emping' (common name of the traditional cracker in Indonesia) and as supplementary soup material. The high purine content of melinjo seeds may cause an increase in uric acid production which can lead to chronic arthritis due to bone erosion (Terkeltaub 2010). Therefore many people are reluctant to consume it. Melinjo peel, as a waste from the process of making emping are seldom used as vegetables, most likely being thrown out (Siswoyo et al. 2011). 
Several bioactive compounds are found in melinjo, such as saponins, tannins, and flavonoids (Kato et al. 2011; Santoso et al. 2010; Siswoyo et al. 2011). These compounds have been studied to have potential utilization as drugs or antibody, antimicrobial, pigments or even anti-inflammatory agents (Khan et al. 2003; Rauha et al. 2000; Uboh et al. 2010). Furthermore, a recent study has reported the isolation of stilbenoids isolated from the seeds of melinjo (Kato et al. 2009) which stated these stilbenoids show moderate antimicrobial activity via a diphenyl-picrilhydrazil-hydrate (DPPH) radical scavenging effect, including lipase and $\alpha$-amylase inhibition activity. However, this study focused itself on isolation process of stilbenoids with complex steps and studied biological activities of the extracts generally. On the other hand, a detail investigation specifically on the antimicrobial activity of melinjo extracts has not been reported. In accordance to those findings, where the melinjo contains bioactive compounds, such as saponins, tannins, and flavonoids, and stilbenoids; there is therefore a need to investigate the antibacterial activity of melinjo seed and peel extract which can be applied further in food products or even in drugs. Initially, we hypothesized the mechanism of antibacterial activity of this extract would be by interfering with the synthesis of the bacteria cell wall. Therefore within this study we carried out an antibacterial comparison study between the melinjo extract and common antibiotics used as antibacterial agents (penicillin $\mathrm{G}$ and streptomycin). In addition, to see the cell wall deformation, we carried out SEM analysis to depict clear images of cell wall changes due to the addition of extract into the growth medium. Selected microorganisms used within this study were Staphylococcus aureus ATCC 25953, Bacillus cereus ATCC 10876, Enterobacter aerogenes ATCC 13048, Pseudomonas aeruginosa ATCC 07853 and Aspergillus flavus IPBCC 88.030, which were considered to represent Gram-negative, Gram-positive bacteria and also mold. We used bacteria and mold within this study since their cell wall assemblies are different. Consequently, this results in different responses for the cell wall deformation as antimicroorganism added to inhibit the growth of those microorganisms.

\section{MATERIALS AND METHODS}

Microorganisms. Several pathogenic bacteria used for this study, such as Staphylococcus aureus ATCC 25953, Bacillus cereus ATCC 10876, Enterobacter aerogenes ATCC 13048, and Pseudomonas aeruginosa ATCC 07853 were purchased from
American Type Culture Collection (ATCC) Biological research center (BRC), Manassas, VA 20108, USA, whilst Aspergillus flavus IPBCC 88.030 was purchased from Bogor Agricultural University, Bogor, Indonesia. At first glance, all bacteria were activated on each physical growth medium. For bacteria, media used were nutrient agar (NA) and nutrient broth (NB), whereas for fungi (Aspergillus flavus IPBCC 88.030) media used were potato dextrose agar (PDA) and potato dextrose broth (PDB). After the activation, those microorganisms were then preserved in micro-tubes (containing $0.5 \mathrm{~mL}$ activated culture) with addition of glycerol $(50 \% \mathrm{v} / \mathrm{v})$ and finally stored at $-40^{\circ} \mathrm{C}$ until used again.

Reagents and Chemicals. Several pro-analytical organic solvents, such as ethanol, ethyl acetate, and hexane were purchased from Mayky Lovic Tangguh Perkasa, Indonesia. Such media, nutrient agar (NA), potato dextrose agar (PDA), nutrient broth (NB), and potato dextrose broth (PDB) were purchased from Sigma-Aldrich. Especially for NB, the MDL number was MFCD01867738 and we confirmed that it does not have any sodium chloride $(\mathrm{NaCl})$ in its composition. This was very important, since within this study such cell leakage due to the addition of the extract would be carried out in terms of $\mathrm{Ca}^{2+}$ and $\mathrm{K}^{+}$ion determinations. Moreover, two antibiotics, penicillin $G$ and streptomycin were obtained from Meiji Seiyaku (Tokyo, Japan).

Seed and Peel Samples. The ripe melinjo seed and melinjo peel (red color) used in this study were collected in September 2009 from the village of Balekambang Condet, East Jakarta, Indonesia. The plant was identified by the Research Center of Biology, Indonesian Institute of Sciences (LIPI), where a voucher specimen was deposited in Pelita Harapan University (1283/IPH.1.02/If.8/XII/2009).

Extraction of Samples. Removal of water from melinjo seeds and melinjo peels was done using a cabinet dryer. Thus, the dried materials were crushed to reduce the size into powder form and sieved using an abrasive screener (Ø: 35 Mesh). Extraction was carried out using several pro-analytical organic solvents (ethanol, ethyl acetate, and hexane) with a ratio between melinjo materials (seed and peel) to solvent being 1:4. The extraction was carried out at $30^{\circ} \mathrm{C}$, shaken at $150 \mathrm{rpm}$ using an orbital shaker incubator (Type Hotech, Taiwan) for $24 \mathrm{~h}$. The mixture was then filtered using Whatman filter paper no. 4 by assistance of a vacuum pump. The extraction process did not follow the study reported by Sunaryanto et al. (2010), since the sources of bio-actives that act as antimicroorganisms were totally different. Further crude 
extract isolation was done by amplification using a rotary evaporator (Buchi) at $40{ }^{\circ} \mathrm{C}$ and shaken at 75 rpm in round-bottomed flask until crystal or paste appeared. Eventually, the crude extracts were put in a dark bottle and stored at temperature of $4{ }^{\circ} \mathrm{C}$.

Antimicrobial Assay. The antimicrobial assay was carried out using the well-diffusion method according to Bloomfield (1991) with minor modification according to Yasni et al. (2009) for five kinds of microorganism as pre-mentioned above. Each extract resulting using several solvents (ethanol, ethyl acetate, hexane) from different parts of melinjo (seed, peel) was diluted to give several concentrations of the extract $(\mathrm{b} / \mathrm{v})$, such as $0 ; 5 ; 10 ; 15 ; 20 ; 25 \%$. The MIC (Minimal Inhibitory Concentration) and MBC (Minimal Bactericidal Concentration, bactericidal term is used for bacteria) or MFC (Minimal Fungicidal Concentration, fungicidal term is used for fungus) were determined according to Bloomfield (1991). By plotting natural logarithm (ln) of concentration (Mo) in $\mathrm{x}$-axis and inhibition zone square value $\left(\mathrm{Z}^{2}\right)$ in $\mathrm{y}$-axis, the value that crosses $\mathrm{x}=0$ will be Mt. Furthermore, MIC was then calculated as $0.25 \mathrm{x}$ Mt and MBC or MFC as $4 \times$ MIC. The determination of the preferred extract was based on the inhibition zone value as reported by Elgayyar et al. (2001) and Suliantari et al. (2008). Following this method, statistical software SPSS 16.0 was used to run one way ANOVA in giving a conclusion as to which extract would be preferred at low concentration gives higher inhibition zone.

Anti-Sporal Activity. Generally an anti-spore is defined as a compound that has the ability to inhibit spore activity (Jenson and Moir 2003). Determination of anti-sporal activity from a preferred extract onto spore-forming bacteria B. cereus ATCC 10876 was conducted using the well-diffusion method. The inhibition zone for $B$. cereus spores (culture was incubated for $48 \mathrm{~h}$ ) was compared with the inhibition zone for vegetative cells of $B$. Cereus ATCC 10876 (culture was incubated for $8 \mathrm{~h}$ ). The statistical analysis was carried out employing the $t$-test $(\mathrm{p}<0.05)$. Each experiment was run in duplicate, and mean values were calculated. A statistical package (SPSS version 16.0) was used for the data analysis.

Antibiotics Testing Comparison. This test was carried out to compare the performance between preferred extract of melinjo and several antibiotics that have antibacterial capacity. The procedure was by varying the concentration of antiotics and the inhibition diameter was then evaluated using the welldiffusion method.

Atomic Absorption Spectrophotometer (AAS) Analysis. To determine the presence of leakage of bacterial cells, AAS analysis was conducted within this study which focused on Calcium ions $\left(\mathrm{Ca}^{2+}\right)$ and Potassium ions $\left(\mathrm{K}^{+}\right)$quantification. The bacterial strains were activated using NB for $8 \mathrm{~h}$. Freshly activated bacteria were collected by centrifuging the broth at $4032 \times \mathrm{g}$ force (rotating at $6000 \mathrm{rpm}$; radius of rotor $100 \mathrm{~mm}$ ) for $15 \mathrm{~min}$. Cells were then washed for several times using de-mineral water and finally resuspended again in $10 \mathrm{ml}$ de-mineral water in a reaction tube for each bacterial strain. Into the tube, a preferred extract concentration was added and then incubated for $24 \mathrm{~h}$. The quantification method of those cations followed the procedure of Prashar et al. (2003), where the suspension was then analyzed to determined $\mathrm{Ca}^{2+}$ at $422.7 \mathrm{~nm}$, whilst $\mathrm{K}^{+}$at $766.5 \mathrm{~nm}$ using AAS instrument (AAS type Shimadzu AA-680).

Scanning Electron Microscope (SEM) Analysis. To determine the efficacy of extract and the morphological changes, SEM studies were performed on tested bacteria treated with preferred melinjo extract. Controls were prepared without melinjo extract. The bacterial samples were washed gently and gradually with $2 \%$ glutaraldehyde solution, $2 \%$ tannic acid solution, buffer solution ( $0.1 \mathrm{M}$ sodium cacodylate containing $10 \mathrm{mM} \mathrm{MgSO}_{4}, \mathrm{pH} 6.7$ ), and $1 \%$ osmium tetraoxide solution. Each specimen was dehydrated using sequential exposure per ethanol concentrations ranging from $50-100 \%$. The ethanol was replaced by tertiary butyl alcohol. After dehydration, the specimen was put onto a stub. Finally, the specimen was sputter-coated with gold (Aurum) in an ion coater for $5 \mathrm{~min}$, followed by microscopic examinations (SEM type JSM-5310 LV) with a magnification of 10,000-15,000 times.

Statistical Analysis. The data was analyzed using one-way analysis of variance (ANOVA) for repeated measurements using statistical software SPSS 16.0 for windows. The Duncan's multiple range tests was used to determine differences at each point. Differences at each point were considered significant at $P \leq 0.05$.

\section{RESULTS}

Extraction. Crude extracts obtained from melinjo seed tended to be colored as brownish yellow in color, while the extract obtained from the melinjo peel was dark red. Within this study, both melinjo seed and peel could be extracted with ethanol, $10.25 \%$, and $13.33 \%$, respectively (Table 1). Conclusively, through the yield percentage of this investigation, the dominant components contained in melinjo seed or melinjo peel were polar, as reflected by higher yield using polar solvent. 
Table 1 Yield of melinjo seed and peel extracts

\begin{tabular}{clr}
\hline Plant sample & Solvent & Yield (\%) \\
\hline \multirow{3}{*}{ Melinjo seeds } & Ethanol & 10.25 \\
& Ethyl acetate & 2.31 \\
& Hexane & 0.00 \\
\hline \multirow{3}{*}{ Melinjo peels } & Ethanol & 13.33 \\
& Ethyl acetate & 2.43 \\
& Hexane & 1.51 \\
\hline
\end{tabular}

Antimicrobial Activity of Seed-based and Peelbased Melinjo Extract. The results showed that Aspergillus flavus IPBCC 88.030 could not be inhibited by either melinjo seed and peel extract since even the highest concentration applied $(25 \% \mathrm{w} / \mathrm{v})$ into the wells, the growth of this fungus could not be inhibited. In addition, the extract inhibition towards Gram-positive bacteria (B. cereus ATCC 10876 and $S$. aureus ATCC 25953) was positively higher than for Gram-negative bacteria (E. aerogenes ATCC 13048 and $P$. aeruginosa ATCC 0785) (Fig 1, 2, 3, and 4).
Minimum Inhibitory Concentration and Minimum Bactericidal Concentration. From the MIC and MBC values (shown in Table 2), melinjo seed - ethanol extract has the lowest MIC and MBC values. Therefore, conclusively, melinjo seeds - ethanol extract was the most effective extract that could inhibit bacterial growth for both Gram-negative and Grampositive bacteria, as compared to other melinjo extracts through the exception of inhibition to mold growth (A. flavus IPBCC 88.030). There were not any MIC and MFC values for $A$. flavus. Representative images to depict inhibition zone, could be seen in Fig 5 which ethanol was used as the solvent and source of extract was melinjo peel. In addition, the preferred extract was chosen according to Suliantari et al. (2008), summarized in Table 3.

Anti-sporal Activity. Anti-sporal activity of preferred melinjo extract can be observed by contacting the extract with spores. The number of

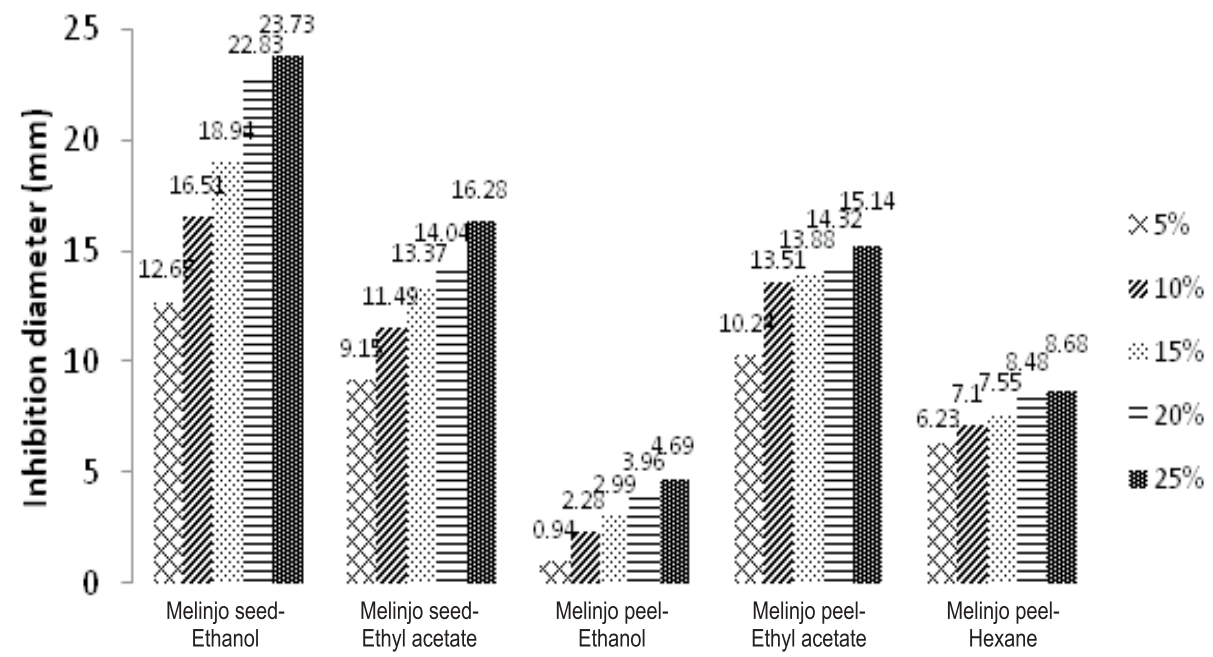

Fig 1 Inhibition diameter of melinjo extracts (source of extract-solvent used) against Bacillus cereus.



Fig 2 Inhibition diameter of melinjo extracts (source of extract-solvent used) against Staphylococcus aureus. 


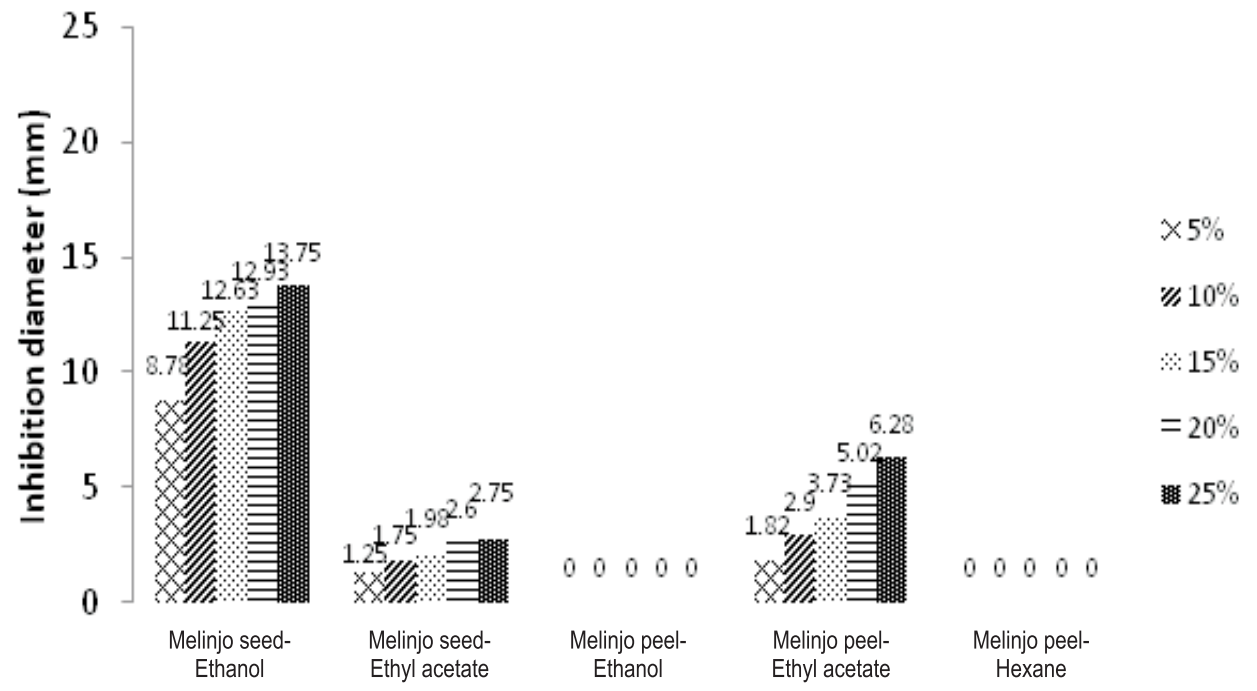

Fig 3 Inhibition diameter of melinjo extracts (source of extract-solvent used) against Enterobacter aerogenes.

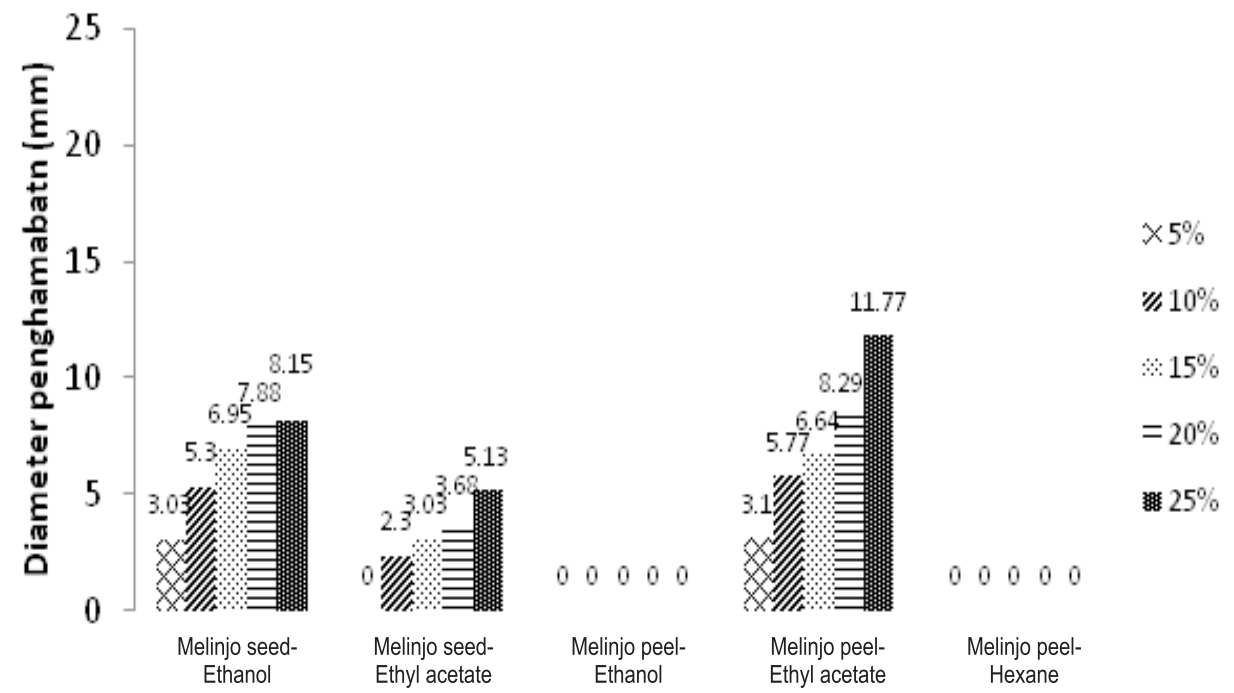

Fig 4 Inhibition diameter of melinjo extracts (source of extract - solvent used) against Pseudomonas aeruginosa.

spores is large when the bacterial culture is incubated for 48 hours (Fig 6). According to the results of statistic analysis $(\mathrm{p}<0.05)$, there was a significant difference between anti-sporal activity of extract onto spores of $B$. cereus $(10.18 \mathrm{~mm})$ and anti-bacterial activity of extract towards vegetative cells of $B$. cereus $(12.83 \mathrm{~mm})$.

Antibiotics Comparison Testing. The results from comparison testing of antibiotics and preferred extracts were shown (Fig 7 and 8). According to the overall results, it was known the inhibition capability of preferred extracts was nearly comparable with $10 \mathrm{ppm}$ of tested antibiotics (Fig 7 for comparison with penicillin $G$ and Fig 8 for comparison with streptomycin).

Atomic Absorption Spectroscopy (AAS) Analysis. Potassium ions $\left(\mathrm{K}^{+}\right)$exist on a bacterial cytoplasm membranes which have functionality on membrane transportation process. Calcium ions $\left(\mathrm{Ca}^{2+}\right)$ and magnesium ions $\left(\mathrm{Mg}^{2+}\right)$ on Gram-negative bacteria are used as a bridge for phospholipid components on cell wall. The ions $\mathrm{Ca}^{2+}$ and $\mathrm{K}^{+}$can be detected after the bacteria have been in contact with the extract. This indicates that the destruction or collapse was happened on the bacteria cell membrane, which might cause the extraction of ions of $\mathrm{Ca}^{2+}$ and $\mathrm{K}^{+}$from the body of a detected cell by AAS. As seen on the Table 4, the amount of $\mathrm{Ca}^{2+}$ that has been detected on Gramnegative bacteria $\left(73.17 \mathrm{mg} \mathrm{L}^{-1}\right.$ and $\left.62.41 \mathrm{mg} \mathrm{L}^{-1}\right)$ was larger as compared to Gram-positive bacteria (58.27 $\mathrm{mg} \mathrm{L}^{-1}$ and $67.17 \mathrm{mg} \mathrm{L}^{-1}$ ).

Scanning Electron Microscope (SEM) Imaging. The morphological changes on the bacteria cell surface can be detected using SEM. There were some morphological changes in B. cereus, $S$. aureus, and $E$. aerogenes which treated with $5 \%$ melinjo seeds ethanol extract and $P$. aeruginosa which was treated with $15 \%$ melinjo peels - ethyl acetate extract (Fig 9). Morphological changes that occurred include 
Tabel 2 Minimal Inhibitory Concentration (MIC) and Minimal Bactericidal Concentration (MBC) values of melinjo extract using different sources (seed, peel) and different solvents (ethanol, ethyl acetate, hexane)

\begin{tabular}{|c|c|c|c|}
\hline Bacterium & Melinjo extracts & $\mathrm{MIC}\left(\mu \mathrm{g} \mathrm{mL} L^{-1}\right)$ & $\operatorname{MBC}\left(\mu \mathrm{g} \mathrm{mL} L^{-1}\right)$ \\
\hline \multirow{5}{*}{ Bacillus cereus } & Melinjo seed - ethanol extract & 0.76 & 3.03 \\
\hline & Melinjo seed - ethyl acetate extract & 0.86 & 3.45 \\
\hline & Melinjo peel - ethanol extract & 1.40 & 5.58 \\
\hline & Melinjo peel - ethyl acetate extract & 0.26 & 1.02 \\
\hline & Melinjo peel - hexane extract & 0.26 & 1.04 \\
\hline \multirow{5}{*}{ Staphylococcus aureus } & Melinjo seed - ethanol extract & 0.15 & 0.58 \\
\hline & Melinjo seed - ethyl acetate extract & 1.19 & 4.76 \\
\hline & Melinjo peel - ethanol extract & 0.90 & 3.58 \\
\hline & Melinjo peel - ethyl acetate extract & 1.46 & 5.82 \\
\hline & Melinjo peel - hexane extract & 0.00 & 0.00 \\
\hline \multirow{5}{*}{ Enterobacter aerogenes } & Melinjo seed - ethanol extract & 0.40 & 1.58 \\
\hline & Melinjo seed - ethyl acetate extract & 0.97 & 3.86 \\
\hline & Melinjo peel - ethanol extract & 0.00 & 0.00 \\
\hline & Melinjo peel - ethyl acetate extract & 1.35 & 5.39 \\
\hline & Melinjo peel - hexane extract & 0.00 & 0.00 \\
\hline \multirow{5}{*}{ Pseudomonas aeruginosa } & Melinjo seed - ethanol extract & 1.04 & 4.15 \\
\hline & Melinjo seed - ethyl acetate extract & 1.51 & 6.04 \\
\hline & Melinjo peel - ethanol extract & 0.00 & 0.00 \\
\hline & Melinjo peel - ethyl acetate extract & 1.36 & 5.43 \\
\hline & Melinjo peel - hexane extract & 0.00 & 0.00 \\
\hline
\end{tabular}



Fig 5 Representative images of inhibition zone of ethanol extract from melinjo seed.

Table 3 Preferred extract for each tested bacteria

\begin{tabular}{ll}
\hline \multicolumn{1}{c}{ Bacteria } & \multicolumn{1}{c}{ Preferred extract } \\
\hline Bacillus cereus & $5 \%$ of melinjo seed - ethanol extract \\
Staphylococcus aureus & $5 \%$ of melinjo seed - ethanol extract \\
Enterobacter aerogenes & $5 \%$ of melinjo seed - ethanol extract \\
Pseudomonas aeruginosa & $\begin{array}{l}15 \% \text { of melinjo peel - ethyl acetate } \\
\text { extract }\end{array}$ \\
\hline
\end{tabular}

leakage (Fig 9f), pore formation (Fig. 9h) and lysis of the membranes integrity (Fig 9b, 9h), and bumps (Fig 9b, 9d, 9f, 9h). Cell shapes became abnormal caused by the penetration of extract into cells which caused swelling in some cells (Fig 9d, 9h) and rough surfaces as compare to the smooth ones of untreated cells. 


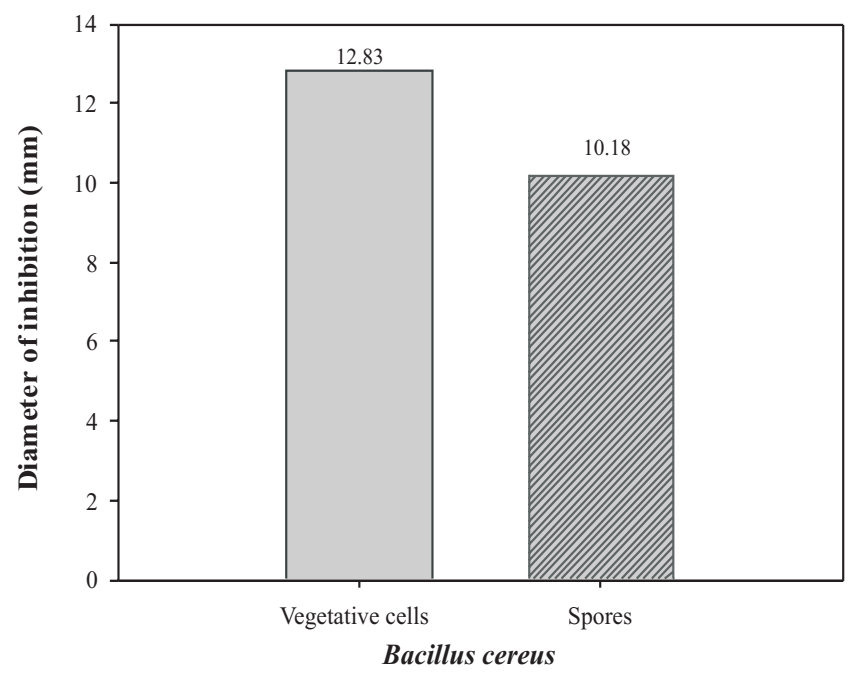

Fig 6 Diameter of inhibition resulting from 5\% melinjo seed-ethanol extract against vegetative cells and spores of Bacillus cereus.

\section{DISCUSSIONS}

Melinjo seed and melinjo peel extract showed antibacterial activity against $B$. cereus, $S$. aureus, $E$. aerogenes, and $P$. aeruginosa, but did not show antifungal activity because it could not inhibit Aspergillus flavus growth. None of the extracts could inhibit the growth of $A$. flavus could be explained as fungus is eukaryotic organism that has cell wall which contains very stiff chitin (Yokoi et al. 1998). This chitin fundamentally contributes to fungal cell wall strength and stability and prevents outer material from penetrating. Furthermore, it may be expected that an extract could not interfere with the permeability of $P$. aeruginosa cytoplasmic membrane because extracts did not have any reaction with sterol inside a mold's cytoplasmic membrane (Farkas 1979).



Fig 7 Diameter of inhibition of preferred melinjo extracts and penicillin G against selected bacteria.

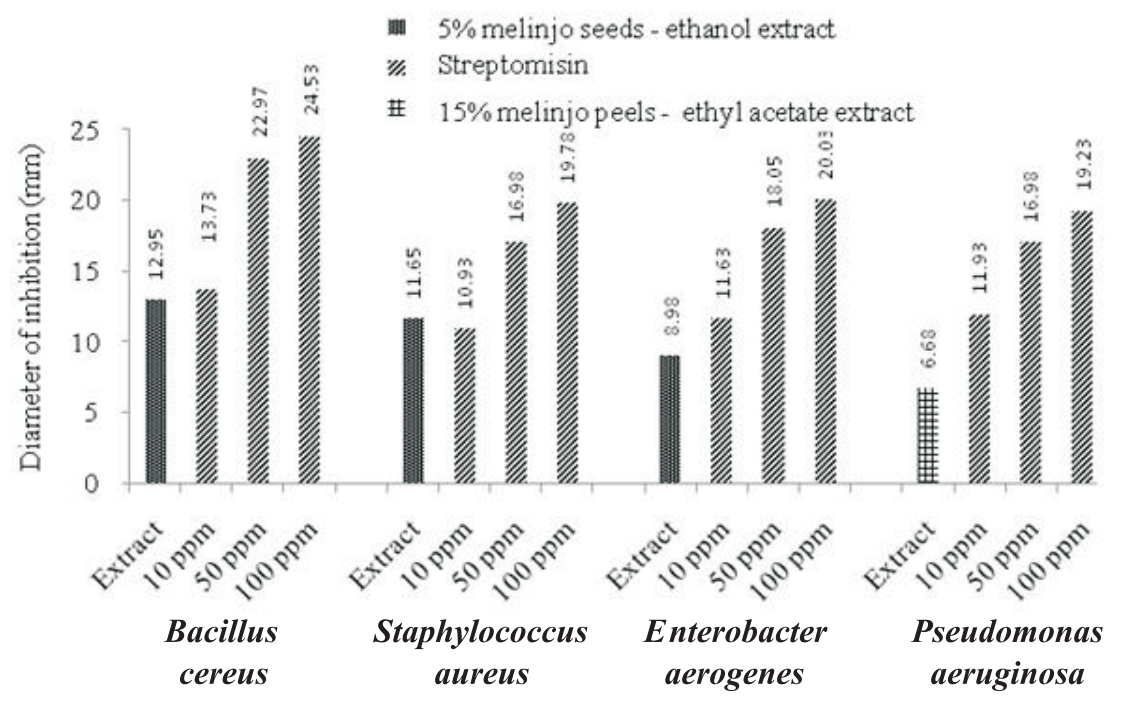

Fig 8 Diameter of inhibition of preferred melinjo extracts and streptomycin against selected bacteria. 
However, melinjo seed and melinjo peel extract have antibacterial activity, proven by the facts that the extract could inhibit the growth of tested bacteria as seen in the inhibition area, and moreover was supported by (i) the MIC and MBC values $(0.26 \sim 1.46 \% ; 1.02 \sim 6.04 \%$ respectively), (ii) anti spore results $(5 \% \mathrm{w} / \mathrm{v}$ of extract), (iii) having the equivalent inhibition capacity as compared to antibiotics (penicillin $\mathrm{G}$ and streptomycin $10 \mathrm{ppm}$ ).

The extract has higher inhibitory effect towards Gram-positive bacteria as compared to Gram-negative bacteria because Gram-negative bacteria have several complex layers on their cell walls. The structure of the cell wall layer on Gram-negative bacteria consists of peptidoglycan and an outer membrane (lipopolysacharide and lipoproteins) (Lesage and Bussey 2006). The existence of an outer membrane cell from Gram-negative bacteria causing the inhibitional diffusion of antimicrobial extract inside both peptidoglycan membranes and bacteria cells and leads to inappropriate conditions for penetrating interacting with inner cell wall components (Fan et al. 1975). In addition, approximately $90 \%$ of a Gram-positive bacteriums cell wall is composed of peptidoglycan, whereas the peptidoglycan layer in the Gram-negative bacterium cell wall is only $50-10 \%$. The outer membrane of Gram-negative bacteria is impermeable to penicillin $\mathrm{G}$, so that bacteria growth can not be inhibited (Tompsett et al. 1947).

For antisporal activity, there was a significant difference between anti-sporal activity of extract onto spores of $B$. cereus $(10.18 \mathrm{~mm})$ and anti-bacterial activity of extract towards vegetative cells of $B$. cereus $(12.83 \mathrm{~mm})$. The layer difference at vegetative cell and endospore level will cause diameter dissimilarity which was produced by the extract. Generally layers of endospore are exosporium layers, spore coats, cortex (Atrih et al. 1998). An enormous layer on it along with its stiff nature, will cause the extract to be harder to diffuse into the cell and inhibit cell growth. Therefore, the inhibition diameter of extract toward spores of $B$. cereus was smaller as compared to its vegetative cells.

For antibiotics comparison testing, the preferred extracts were able to inhibit both Gram-positive and Gram-negative bacteria (Fig 7). However, penicillin G was also found to effectively inhibit Gram-positive bacteria (Fig 7). According to Baldwin et al. (1997), antibacterial activity of penicillin $G$ was due to its interference on the synthesis process of the bacteria cell wall. Though this conclusion needs further clarification, due to this finding, we hypothesize the preferred melinjo extracts should follow the mechanism of penicillin $\mathrm{G}$ inhibition in that they were
Table 4 Total calcium and potassium ions detected by AAS

\begin{tabular}{lcc}
\hline Bacterium & $\begin{array}{c}\text { Total Ca } \\
\left(\mathrm{mg} \mathrm{L}^{-1}\right)\end{array}$ & Total K $\left(\mathrm{mg} \mathrm{L}^{-1}\right)$ \\
\hline Bacillus cereus & 58.27 & 196.39 \\
Staphylococcus aureus & 67.17 & 190.03 \\
Enterobacter aerogenes & 73.17 & 130.06 \\
Pseudomonas aeruginosa & 62.41 & 111.26 \\
\hline
\end{tabular}
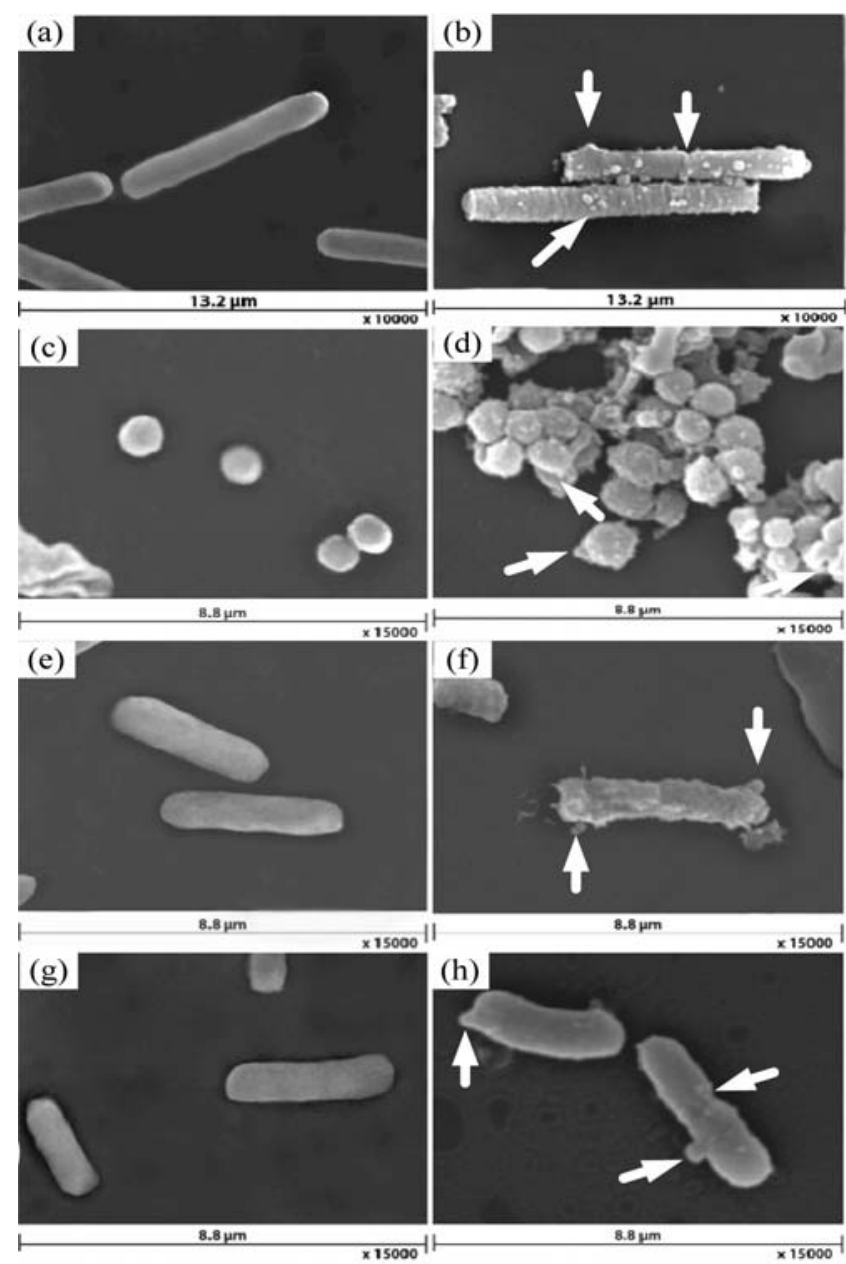

Fig 9 SEM photomicrographs showing the morphological changes of tested bacteria after exposure to preferred melinjo extract (Gnetum gnemon) for each bacteria. a, Bacillus cereus control; b, Bacillus cereus treated with $5 \%$ melinjo seed ethanol extract; c, S. aureus control; d, Staphylococcus aureus treated with 5\% melinjo seed ethanol extract e, Enterobacter aerogenes control; f, Enterobacter aerogenes treated with 5\% melinjo seed ethanol extract; g, Pseudomonas aeruginosa control; h, Pseudomonas aeruginosa treated with 15\% melinjo peel ethyl acetate extract.

able to influence the synthesis process of bacteria cell wall. Streptomycin could inhibit Gram-positive and Gram-negative bacteria. According to Lin et al. (2000), the inhibition mechanism of streptomycin was by attacking the ribosome of microbes which leads to error reading of the mRNA sequence taking place, resulting in the formation of polypeptide which becomes irregular and nonfunctional, and therefore inhibited bacterial growth. The anti-bactericidal activity of the each preferred extract for each bacterium was comparable with the action of streptomycin in inhibiting bacterial growth (Fig 8). Furthermore, we 
suggest the overall inhibition mechanisms of melinjo extracts against bacteria were by interfering with protein synthesis in bacteria, degrading the existing present cell wall or interfering which bacterial cell wall synthesis, and damaging cell membrane of bacteria (as reported by Yasni et al. (2009)) and proven by the analysis of mineral content and SEM imaging system(Fig 9).

According to Parhusip (2006) and Rogers (1970), destruction of bacterial cell membrane may also cause the extraction of minerals the from cell inner side such as, calcium $\left(\mathrm{Ca}^{2+}\right)$ and potassium $\left(\mathrm{K}^{+}\right)$. Therefore, within this study we have found the $\mathrm{K}^{+}$leakage was higher for both Gram-negative and positive bacteria as compared to $\mathrm{Ca}^{2+}$ leakage. Moreover, in the Grampositive bacteria the $\mathrm{K}^{+}$leakage was higher than Gramnegative ones. However, this condition was contrary to $\mathrm{Ca}^{2+}$ leakage, since the Gram-negative leakage was found to be higher than the Gram-positive ones. This could be explained since the outer membrane of Gramnegative bacteria consists of a large number of $\mathrm{Ca}^{2+}$ ions, whereas Gram-positive bacteria consist of $\mathrm{Ca}^{2+}$ which is located on its cytoplasmic membrane (Farkas 1979). This was also confirmed by the results mentioned by Beveridge (1999).

Lastly, those findings mentioned above were totally confirmed morphologically through SEM imaging (Fig 9). The same imaging phenomenon was also reported by Al-Reza et al. (2010) who mentioned that the essential oil extract of Zizyphus jujuba causes the formation of pores or holes in the cell membrane and cell lysis in S. aureus, which indicates the occurrence of disturbances on the structure of cell membranes. Within this study the same perspective was also found. Moreover, changes in morphology in this study were also similar to results of Shalamanov (2005), including changes in the morphology on Gram-negative bacteria (Enterobacter cloacae, Pseudomonas aeruginosa, and Serratia marcescens) that had been contacted with chlorhexidine gluconate. Changes that occurred were elongation, variations in shape and size of cells, the formation of bumps, grooves and wrinkles on the cell walls. These SEM images were performed to provide basic supportive data on the occurrence of morphological changes in bacteria cells so that the mechanism of melinjo extract action could be deduced. Finally, from these comprehensive data we could conclude that melinjo extract has real potential to be applied in food preservation against selected pathogenic bacteria.

\section{ACKNOWLEDGEMENTS}

We would like to thank Universitas Pelita Harapan (UPH) for the funding, and Elisa FR and Jennifer Octavia for the assistance.

\section{REFERENCES}

Al-Reza SM, Rahman A, Lee J, Kang SC. 2010. Potential roles of essential oil and organic extracts of Zizyphus jujuba in inhibiting food-borne pathogens. Food Chem. 119: 981-986. doi:10.1016/j.foodchem.2009. 07.059 .

Atrih A, Zöllner P, Allmaier G, Williamson MP, Foster SJ. 1998. Peptidoglycan structural dynamics during germination of Bacillus subtilis 168 endospores. J Bacteriol. 180: 4603-4612.

Baldwin JE, Byford MF, Clifton I, Hajdu J, Hensgens C, Roach P, Schofield CJ. 1997. Proteins of the penicillin biosynthesis pathway. Curr Opin Struct Biol.7(6): 857-864.

Beveridge TJ. 1999. Structures of gram-negative cell walls and their derived membrane vesicles. J Bacteriol. 181(16): 4725-4733.

Bloomfield SF. 1991. Methods for assessing antimicrobial activity. In: Denyer SP, Hugo WB, editors. Mechanisms of action of chemical biocides their study and exploitation. Blackwell Scientific Publication: London.

Elgayyar M, Draughon FA, Golden DA, Mount JR. 2001. Antimicrobial activity of essential oils from plants againts selected patogenic and saprophytic microorganisms. J Food Protect. 64(7): 1019-1024.

Fan DP, Beckman BE, Gardner-Eckstrom HL. 1975. Mode of cell wall synthesis in gram-positive bacilli. J Bacteriol.123: 1157-1162.

Farkas V. 1979. Biosynthesis of cell walls of fungi. Microbiol Rev. 43(2): 117-144.

Hafif B, Masbulan E, Suwardjo H. 1995. Peluang melinjo (Gnetum gnemon) sebagai bagian tanaman konservasi pada daerah aliran air pada daerah semi arid. [The opportunity of melinjo (Gnetum gnemon) as conservation farming component at the upland watershed in semiarid climate]. In: Proceedings of the symposium on $4^{\text {th }}$ agricultural meteorology: climate analysis for agribusiness development; 1995 Maret 3-5. Bogor (ID). Bogor: PERHIMPI. p 287-298.

Jenson I, Moir CJ. 2003. Bacillus cereus and Other Bacillus Species. In: Hocking, A.D. (ed). Foodborne Microorganisms of Public Health Significance $6^{\text {th }}$ edition. Southwood Press: Australia.

Kato E, Tokunaga Y, Sakan F. 2009. Stilbenoids isolated from the seeds of melinjo (Gnetum gnemon L.) and their biological activity. J Agric Food Chem. 57(6): 2544-2549. doi: 10.1021/jf803077p.

Kato H, Samizo M, Kawabata R, Takano F, Ohta T. 2011. Stilbenoids from the melinjo (Gnetum gnemon L.) fruit modulate cytokine production in murine peyer's patch cells ex vivo. Planta Med. 77(10):1027-1034.

Khan MR, Omoloso AD, Kihara M. 2003. Antibacterial activity of Artocarpus heterophyllus. Fitoterapia. 74(5): 501-505.

Lesage G, Bussey H. 2006. Cell Wall Assembly in Saccharomyces cerevisiae. Microbiol Mol Biol Reviews. 70(2): 317-343. doi: 10.1099/mic.0.26471-0.

Lin CM, Preston JF, Wei CI. 2000. Antibacterial mechanism of allyl isothiocyanate. J Food Protect. 63(6): 727-734.

Manner HI, Elevitch CR. 2006. Gnetum gnemon (gnetum). In: Traditional trees of specific islands: their culture, environment and use. Holualoa: CR Elevitch.

Parhusip A. 2006. Study of antibacterial mechanism of andaliman extract (Zanthoxylum acanthopodium DC) towards food pathogen bacteria [dissertation]. Bogor(ID): Institut Pertanian Bogor.

Prashar A, Hili P, Veness RG, Evans CS. 2003. Antimicrobial action of palmarosa oil (Cymbopogon martinii) on Saccharomyces cerevisiae. Phytochemistry. 63: 569-575. doi:10.1016/S0031-9422(03)00226-7.

Rauha JP, Remes S, Heinonen M, Hopia A, Kähkönen M, Kujala T, Pihlaja K, Vuorela H, Vuorela P. 2000. Antimicrobial effects of finish plant extracts containing flavonoids and other phenolic compounds. Int. J Food Microbiol. 56(1): 3-12. doi:10.1016/S00319422(03)00226-7.

Rogers HJ. 1970. Bacterial growth and the cell envelope. Bacteriol Rev. 34(2): 194-214.

Shalamanov DS. 2005. Chlorhexidine gluconate-induced morphological changes in Gram negative microorganisms. Biotechnol Biotechnol Equip. 19(1): 121-124. 
Santoso M, Naka Y, Angkawidjaja C, Yamaguchi T, Matoba T, Takamura H. 2010 Antioxidant and DNA damage prevention activities of the edible parts of Gnetum gnemon and their changes upon heat treatment. Food Sci Technol Res. 16(6):549-556.

Suliantari, Jenie BSL, Suhartono MT, Apriyantono A. 2008. Aktivitas antibakteri ekstrak sirih hijau (Piper betle L.) terhadap bakteri patogen pangan [Antibacterial activity of green sirih (Piper betle L) extract towards food pathogens]. J Teknol Ind Pangan. 19(1): 1-7.

Sunaryanto R, Bambang M, Tun TI, Zainal AM, Liesbetini H. 2010. Isolation and characterization of antimicrobial substance from marine Streptomyces sp. Microbiol Indones. 4(2): 84-89.

Terkeltaub R. 2010. Update on gout: new therapeutic strategies and options. Nat Rev Rheumatol. 6:30-38. doi:10.1038/nrrheum.2009.236.
Tompsett R, Shultz S, McDermott W. 1947. The relation of protein binding to the pharmacology and antibacterial activity of penicillins $\mathrm{X}, \mathrm{G}$, dihydro F, and K. J Bacteriol.53: 581-595.

Uboh FE, Okon IE, Ekong MB. 2010. Effect of aqueous extract of Psidium guajava leaves on liver, enzymes, histological integrity and hematological indices in rats. Gastroenterol Res. 3(1): 32-38.

Yasni S, Elvira S, Eva HD. 2009. Antimicrobial activity of black cumin extracts (nigella sativa) against food pathogenic and spoilage bacteria. Microbiol Indones. 3(3): 146-150.

Yokoi H, Aratake T, Nishio S, Hirose J, Hayashi S, Takasaki Y. 1998. Chitosan production from Shochu distillery wastewater by fungi. J Ferment Bioeng.85: 246249. doi:10.1016/S1389-1723(02)80061-5. 